\title{
Training-professional profile of nurses teaching at the Technical Schools of the Unified Health System
}

\author{
Perfil formativo-profissional dos enfermeiros docentes das Escolas Técnicas do Sistema Único de Saúde \\ Perfil formación-profesional del enfermero docente en las Escuelas Técnicas del Sistema Único de Salud
}

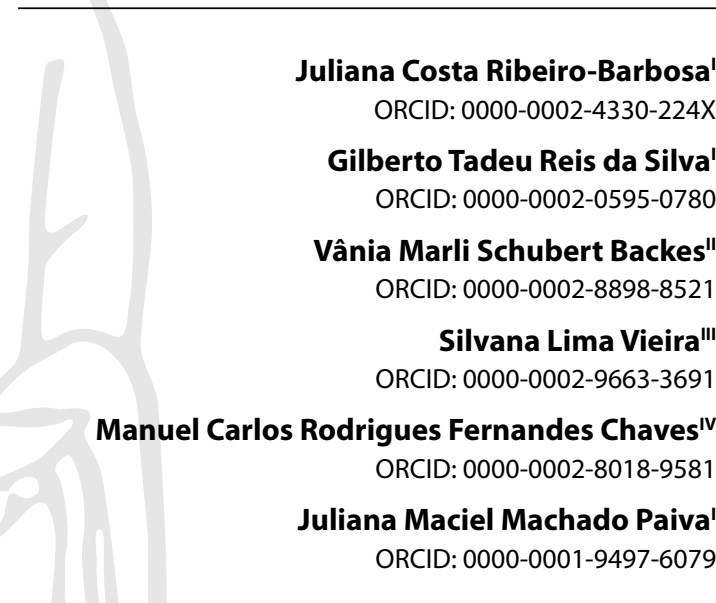

'Universidade Federal da Bahia. Salvador, Bahia, Brazil. "Universidade Federal de Santa Catarina. Florianópolis, Santa Catarina, Brazil.

"'Universidade do Estado da Bahia. Salvador, Bahia, Brazil.

"Escola Superior de Enfermagem de Coimbra.

Coimbra, Portugal.

How to cite this article:

Ribeiro-Barbosa JC, Silva GTR, Backes VMS, Vieira SL, Chaves MCRF, Paiva JMM. Training-professional profile of nurses teaching at the Technical Schools of the Unified Health System. Rev Bras Enferm. 2022;75(2):e20201142. https://doi.org/10.1590/0034-7167-2020-1142

Corresponding author: Juliana Costa Ribeiro-Barbosa E-mail:enfa.jcr@hotmail.com

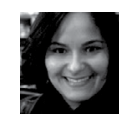

EDITOR IN CHIEF: Antonio José de Almeida Filho ASSOCIATE EDITOR: Maria Itayra Padilha

Submission: 11-11-2020

Approval: 05-17-2021

\begin{abstract}
Objective: to describe the training-professional profile of nursing professors in the vocational course in nursing at the Technical Schools of the Unified Health System. Methods: a quantitative descriptive research, carried out with 61 nurses who are professors of technical courses in nursing at five technical schools in three Brazilian regions. Data were collected through an online questionnaire and submitted to descriptive analysis. Results: only $36 \%$ of teaching nurses were licensed and $80 \%$ had a specialization in nursing or health. Although $95.1 \%$ of participants considered training for teaching necessary, $44.2 \%$ did not have qualifications for this job. The average length of work in care was 8 years, focusing on the hospital network. Conclusion: the need for professor training and investment in it is evidenced, as the training of essential workers for nursing care and consolidation of the Unified Health System is on the agenda. Descriptors: Faculty, Nursing; Faculty; Education, Nursing, Associate; Nursing; Unified Health System.
\end{abstract}

\section{RESUMO}

Objetivo: descrever o perfil formativo-profissional dos enfermeiros docentes do curso técnico em enfermagem das Escolas Técnicas do Sistema Único de Saúde. Métodos: pesquisa quantitativa, do tipo descritiva, realizada com 61 enfermeiros professores de cursos técnicos em enfermagem de cinco escolas técnicas de três regiões brasileiras. Os dados foram coletados por questionário online e submetidos à análise descritiva. Resultados: destaca-se que apenas $36 \%$ dos enfermeiros docentes eram licenciados e $80 \%$ tinham especialização na área de enfermagem ou saúde. Apesar de $95,1 \%$ dos participantes considerar necessária a formação para o ensino, $44,2 \%$ não tinha qualificação para este trabalho. $O$ tempo médio de atuação na assistência foi de 8 anos, concentrando-se na rede hospitalar. Conclusão: evidencia-se a necessidade de formação docente e o investimento nesta, pois está em pauta a formação de trabalhadores essenciais para o cuidado em enfermagem e consolidação do Sistema Único de Saúde. Descritores: Docentes de Enfermagem; Docentes; Educação Técnica em Enfermagem; Enfermagem; Sistema Único de Saúde.

\section{RESUMEN}

Objetivo: describir el perfil formativo-profesional de los profesores de enfermería en el curso técnico en enfermería de las Escuelas Técnicas del Sistema Único de Salud. Métodos: investigación cuantitativa, descriptiva, realizada con 61 enfermeras que son profesoras de cursos técnicos en enfermería en cinco escuelas técnicas en tres regiones brasileñas. Los datos se recopilaron a través de un cuestionario en línea y se sometieron a análisis descriptivo. Resultados: se destaca que solo el $36 \%$ de los profesores de enfermería tenía licencia y el $80 \%$ tenía especialización en el campo de la enfermería o la salud. Si bien el $95,1 \%$ de los participantes consideró necesaria la formación para la docencia, el $44,2 \%$ no tenía la calificación para este puesto. El tiempo promedio de experiencia en la atención fue de 8 años, con foco en la red hospitalaria. Conclusión: se evidencia la necesidad de formación e inversión docente en la misma, ya que la formación de los trabajadores esenciales para la atención de enfermería y la consolidación del Sistema Único de Salud está en la agenda. Descriptores: Docentes de Enfermería; Docentes; Graduación en Auxiliar de Enfermería; Enfermería; Sistema Único de Salud. 


\section{INTRODUCTION}

Studies that have as their object of investigation the training and professional profile of workers enable a general analysis of their processes and aspects so that it is possible to understand to what extent and how they occur and, consequently, allow to point out possible existing strengths and weaknesses ${ }^{(1-2)}$. Recognizing this profile goes beyond the characterization, considering that it can contribute to the planning and development of strategies as more targeted and resolute responses with a focus on the challenges that present themselves.

In the case of nursing professors of Middle-Level Technical Professional Education (EPTNM - Educação Profissional Técnica de Nível Médio) in nursing, knowing this profile is essential, as they are involved in the training of professionals who represent a significant contingent of workers and who have fundamental attributions in nursing care and health. In numbers, among the professionals that make up the nursing team, the mid-level technicians' workforce corresponds to approximately $57 \%$, i.e., it is equivalent to about one million three hundred thousand workers ${ }^{(3)}$.

In the context of Technical schools of the Unified Health System (ETSUS - Escolas Técnicas do Sistema Único de Saúde), institutions that play a significant role in training for the Unified Health System (SUS - Sistema Único de Saúde), as they base their educational processes on the guidelines of this system, the training and professional performance of nursing professors occupy a more relevant space, given the commitment of these schools to critical, civic education that responds to the population's health needs ${ }^{(4-5)}$. So, analyzing their training-professional profile is essential, because, in addition to raising information about who they are and about the paths taken to become professors in professional nursing education, such information subsidizes the (re)formulation of policies and practices aimed at to professor training concatenated with the complexity and particularities inherent in teaching itself.

Furthermore, there is a lack of studies that address this object, an aspect proven through a search in Virtual Health Library in April 2021, using the descriptors "nursing professors" AND "technical education in nursing", which identified 43 publications, none of which dealt with the object in focus.

Finally, it is known that many nurses enter teaching without the necessary training for this job ${ }^{(6-7)}$. It should be noted that teaching is a profession and, therefore, it has specificities that demand the acquisition of different knowledge, therefore, training directed to its exercise ${ }^{(8-9)}$. In support, Shulman ${ }^{(8)}$, in his theoretical framework of Knowledge Base for Teaching, describes at least seven categories of knowledge necessary for professors to teach: general pedagogical, content, students, curriculum, pedagogical the content, educational contexts and the purposes, purposes and values of education.

\section{OBJECTIVE}

To describe the training-professional profile of nursing professors in the vocational course in nursing at the Technical Schools of the Unified Health System.

\section{METHODS}

\section{Ethical aspects}

The study observed the ethical and scientific principles for research with human beings specified in Resolutions 466/2012 and 510/2016 of the Brazilian National Health Board (Conselho Nacional de Saúde) and was approved by an Institutional Review Board. It should be noted that all participants signed the Informed Consent Form.

\section{Study design and period}

This is a quantitative, descriptive study, developed in five Technical Schools of the Unified Health System in three Brazilian regions, between January and October 2019.

\section{Study site}

The ETSUS participating in the study are located in Acre, Amazonas, Ceará, Paraná and Santa Catarina, one in each state. Brazil has 41 ETSUS present in all states, of which 05 had ongoing classes of the course in focus, a characteristic considered as a criterion for the inclusion of the school in the research. It is noteworthy that contact with each of the 41 schools was made prior to data collection, which began in January 2019 by telephone. Subsequently, a cover letter, the co-participating Institution Authorization Statement and a copy of the full research project were sent by email to the ETSUS that met the established inclusion criteria.

\section{Study population, and inclusion and exclusion criteria}

Sixty-one nurses, professors of nursing technical courses from five ETSUS from three geographic regions of Brazil, who had classes in progress during the period of data collection, participated in the study. Professionals graduated in nursing and having been a professor, teaching or scheduled to act as a professor in the ongoing class of the technical nursing course were included. Professionals on leave, vacation or away from work at the time of data collection were excluded.

The contact and invitation to participants took place in September 2019 through email or message exchange application, with the support of school secretaries who provided a list containing the name, education and email and/or telephone contact of all professors. From the census survey, out of a total of 73 professors, 66 were nurses, to whom an invitation was made to participate in the study. Thus, considering the inclusion and exclusion criteria mentioned above, the study was structured with an $n=61$, obtaining acceptance of $92.4 \%$ of the total number of nursing professors.

\section{Data collection and organization}

Data collection took place in October 2019, using an online questionnaire consisting of 21 open and closed questions, organized into 4 sections: section 1, characterization of participants - age, gender and type of institutional affiliation; section 2, training profile - type and year of graduation in nursing and other training at a technical, higher or graduate level; section 3, professional profile of work in teaching-year, motivation for admission and length of experience 
in teaching, experiences in nursing education and participation in a professor training course; and section 4, professional profile of work in care - year of admission, time and place of work in care.

The questionnaire link, created on Google Forms, was made available by email or message exchange application, as chosen by participants. Data were automatically gathered with each answer, in a spreadsheet in Microsoft ${ }^{\circ}$ Excel, allowing its wide and detailed visualization.

\section{Analysis of results}

For treatment and analysis, descriptive analysis was used, which makes it possible to summarize, summarize, compare and explore the data behavior, representing them through graphs, a table presented in absolute numbers and percentage indices, percentages, median, and mean ${ }^{(10)}$.

\section{RESULTS}

The results, described below, present participants' characterization, and the others are arranged in two sections named "Training profile of nursing professors at the technical level" and "Professional profile of nursing professors at the technical level", the latter subdivided into two dimensions entitled "Performance in teaching" and "Performance in care".

Nursing professors $(n=61)$ had a mean age of 38 years, $81.9 \%(50)$ were female and $93.4 \%$ (57) had a temporary institutional link (Table 1).

Table 1 - Characterization of nursing professors according to age, gender and institutional affiliation ( $n=61$ ), Salvador Bahia Brazil, 2019

\begin{tabular}{lcc}
\hline Variable & $\mathbf{n}$ & \% \\
\hline Sex & & \\
$\quad$ Female & 50 & 81.9 \\
$\quad$ Male & 11 & 19.1 \\
Age & & \\
20 to 29 & 9 & 14.8 \\
30 to 39 & 31 & 50.8 \\
40 to 49 & 14 & 23.0 \\
50 years and older & 7 & 11.4 \\
Type of institutional relationship & & \\
$\quad$ Temporary & 57 & 93.4 \\
$\quad$ Hired & 4 & 6.6 \\
\hline
\end{tabular}

Training profile of nursing professors at the technical level

Nursing professors' training profile considered the following characteristics: course typology and time of completion of nursing graduation, training in another graduation and/or professional training and graduate courses.

Regarding the typology of undergraduate nursing, 64\% (39) of participants had completed a bachelor's degree in nursing, and $36 \%$ (22) had also completed a degree in nursing. When considering the time since graduation, in turn, there was a variation between 2 and 37 years, with a median equal to 10 years.

Regarding other training in a vocational course or at the undergraduate level, $44.3 \%$ (27) of participants said they had it. Of these, $66.6 \%$ (18) had completed a technical course, especially the nursing technician, who made up $77.8 \%$ (14), and one, who had completed the nursing assistant course. Regarding another degree, in addition to nursing, $29.6 \%$ (8) reported having graduated from another higher-level course: biological sciences $(n=2,25 \%)$, law $(n=1,12.5 \%)$, public management $(n=1,12.5 \%)$, history $(n=1$, $12.5 \%)$, veterinary medicine $(n=1,12.5 \%)$, and pedagogy $(n=2$, $25 \%)$. It is noteworthy the fact that only one was in the health area. In addition, $11.1 \%$ (3) had, at the same time, training in both a professional training course and a higher level, in addition to their own undergraduate degree in nursing.

Therefore, with regard to graduate studies, $91.8 \%$ (56) of nursing professors held a graduate degree, as shown in Figure 1.

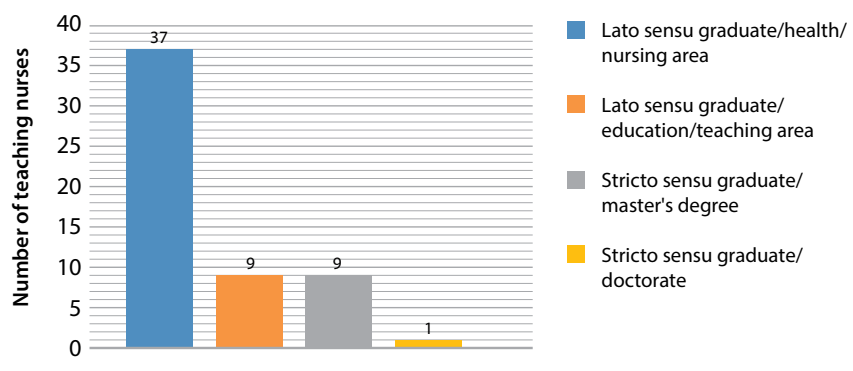

Figure 1 - Number of nursing professors with graduate degrees according to typology, Salvador, Bahia, Brazil, 2019

Also related to data concerning graduate nurses, according to Figure $1,82.1 \%$ (46) were specialists, $16.1 \%$ (9) had a master's degree and $1.8 \%$ (1) had completed a doctorate. Regarding the area of specialization, $80 \%$ (37) of the courses were in the area of health or nursing, and $20 \%$ (9) in education and/or teaching.

\section{Professional profile of nursing professors at the technical level}

The professional profile of nursing professors was subdivided into two dimensions: Performance in teaching; Performance in care.

\section{Performance in teaching}

The characterization of nursing professors' professional profile, in view of their work in teaching, considered the time they started in teaching after completing their undergraduate degree in nursing, motivation for joining teaching, time working in teaching, experiences in nursing education and training for teaching, which are detailed below.

The average time to start teaching after completing the graduation in nursing was 3 years, according to the trend line in the graph below, with $63.9 \%$ (39) of nurses entering teaching within 2 years of graduates (Figure 2).

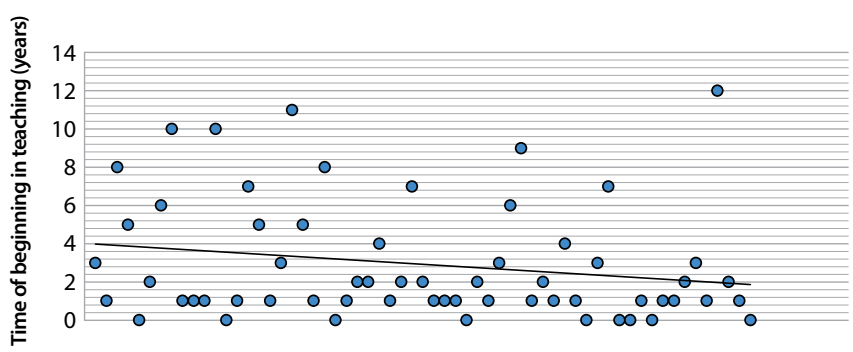

Figure 2 - Distribution of nursing professors according to time of beginning in teaching after graduation in nursing, Salvador, Bahia, Brazil, 2019 
When asked about the motivations that led them to enter teaching, nursing professors' answers were varied, with an emphasis on affinity with teaching $(n=22,36.1 \%)$, the possibility of contributing to the training of future professionals $(n=16$, $26.2 \%$ ) and to keep their knowledge in health and nursing always updated $(n=13,21.3 \%)$. It should be noted that, although little mentioned, financial motivation was also mentioned $(n=5,8.2 \%)$.

Among the participants, $55.7 \%$ (34) were novice professors, whose teaching experience was less than 5 years, $34.4 \%$ (21) were intermediate professors, since they had between 6 and 14 years in teaching, and $9.8 \%$ (6) were experienced professors, as they had worked in the classroom for over 15 years.

Regarding their experiences in nursing education, 57.3\% (35) have already taught in other courses, in addition to the technical one, of which $82.8 \%$ (29) have already had teaching experience at graduation, $45.7 \%$ (16), in graduate school and two in improvement courses. Due to the quantity described, it is noteworthy that these experiences were not exclusive, so that the same participant may have taught in undergraduate, graduate and other courses.

Regarding teaching training, 95.1\% (58) of participants considered it necessary for acting as a professor. When asked if they had any type of teaching qualification, 44.2\% (27) answered no (Figure 3).

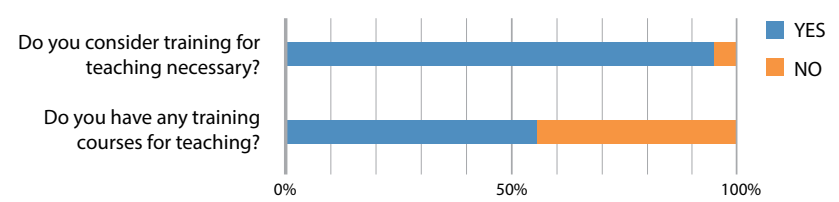

Figure 3 - Nursing professors' responses to questions about training for teaching, Salvador, Bahia, Brazil, 2019

\section{Performance in care}

The characterization of nursing professors' professional profile, taking into account their role in care, was based on the following characteristics: year of admission, time and place of care.

Among the participants, $91.8 \%$ (56) had already worked in care, whose average time of entry into care practice after graduation was 1 year, and of performance, 8 years.

As for the place of work in care, $78.8 \%$ (44) have worked in the hospital network, $44.6 \%$ (25) have worked in the basic network, $32.1 \%$ (18) have been preceptors, $28.5 \%$ (16) already assisted in a specialized service, one has already provided care at home, one has already worked in a pre-hospital service and one did not report where he worked. From the scenario presented, it is noteworthy that $49.2 \%$ (30) of nurses worked in more than one location.

\section{DISCUSSION}

Considering participants' training profile, the results showed that a minority of nursing professors was licensed $(n=22,36 \%)$. It is known that the offer of a bachelor's degree in nursing is significantly predominant when compared to a degree. In a survey carried out in August 2019, it was identified that undergraduate education makes up only $1 \%$ (12) of the total (1168) of undergraduate nursing courses in the context of Brazilian higher education ${ }^{(11)}$.

The observation of this reality allows us to deduce that there is (or always will be) a certain continuity in the performance of bachelors as professors, which points to the fragility of the recognition of teaching as a profession that requires specific training because it has its own particularities and demands. Lee Shulman's Model of the Knowledge Base of Teaching is based on the understanding that teaching is a profession and, therefore, it overcomes the widespread idea that it is enough to have good communication, knowledge of content and apply in the classroom the results of studies on teaching effectiveness to teach ${ }^{(8,12)}$.

Furthermore, considering that a degree in nursing was established as a requirement for the role of nurses in teaching in secondary technical professional education, as it associates the training of generalist nurses with professor training ${ }^{(13-14)}$, this scenario gains even more relevance, since most participants in the present study ( $n=39,64 \%$ ) do not have initial training, ideally designed, for teaching.

It should not be forgotten, either, that the situation in focus involves the training of mid-level nursing workers, who occupy a significant place in health care ${ }^{(5)}$. This professional totals approximately $57 \%$ of the nursing workforce, and their attributions are essential for care ${ }^{(3)}$. Such evidence adds even more significance to the training path and the performance of nursing professors, as they are involved with the training of these workers.

Still, in the characterization of nursing professors' training profile, the time since graduation ranged between 2 and 37 years, with a median equal to 10 years, a relatively considerable length of professional experience. It is interesting to point out that, often, the experience and knowledge from this work can generate the mistaken idea that an experienced nurse necessarily is/will be a good nursing professor. Here, Shulman ${ }^{(8)}$ is resumed, stating that, in addition to knowledge of a specific content of each area of expertise and in the case of nursing, improved with care practice and experience, there are at least six other categories of knowledge underlying professors' performance, as mentioned above. Therefore, expertise in nursing is essential, but insufficient for the educational practice of nurses.

The idea that professional experience is enough to be a good professor can make it difficult for nurses themselves to seek training for teaching, as they anchor their teaching know-how/doing only on theoretical-practical knowledge of their area. In the study in focus, for example, it appears that the majority are specialists $(n=46,82.1 \%)$; however, the inexpressiveness of specialist nurses in the field of education and/or teaching stands out ( $n=9 ; 20 \%$ ), to the detriment of the large number of specialists in general areas of nursing and health care $(n=37 ; 80 \%)$. In fact, the training trajectory of nurses, especially those of a bachelor's degree, at the graduate level, has always been linked to the improvement of knowledge inherent to their area of professional practice ${ }^{(15)}$. In this way, even if they are part of teaching, there is a timid search of nurses for training courses that qualify them for teaching work.

In this context, Shulman ${ }^{(8)}$ also states that graduate studies in a certain area or discipline and, in this case in nursing, are presented as one of the sources of knowledge base for teaching, recognizing its value, as it corresponds to a possibility of academic training that expands and deepens knowledge, important for teaching practice. However, by itself, it does not provide sufficient knowledge that underpins and is indispensable for teaching, so that the need to extrapolate the limits of disciplinarity and seek other knowledge that is also fundamental in the training itinerary and for teaching performance is evidenced. 
The data express a high number of nurses ( $n=27 ; 44.3 \%)$ who have other training, either at the undergraduate or professional level. Of these, the majority $(n=18 ; 66.6 \%)$ had completed some professional training course; among these, the technical course in nursing stood out $(\mathrm{n}=14 ; 77.8 \%)$. Technical professionalization in nursing prior to graduation may point to the most immediate need for insertion in the world of work, given that the health sector is an important employer and the nursing technician, in particular, represents the largest contingent of workers in this field. Furthermore, the search for graduation can signal the search for expansion of knowledge and professional qualification as well as for a certain social ascension ${ }^{(16)}$. Anyway, having taken the technical course in nursing and having continued to study, graduating as a nurse, can refer to education as a determining element for better insertion and professional growth and reveal maintenance of interest in the field of nursing, providing important knowledge of practice.

It is worth noting that, although the mention of other higher education ( $n=8,29.6 \%$ ) was not as significant as in a professional course, the result is interesting in that only one of the participants also graduated in health. The characteristic of nurses having another degree and still outside the health area is not new, although it is not so common. In a study carried out with the objective of tracing the profile of nursing in Brazil, developed in 2013, in partnership with Fundação Oswaldo Cruz and the Federal Nursing Council, it was evidenced that a part of the surveyed nurses, although small, reported having completed or to be attending another degree, and the law course occupied first place in participants' preference ${ }^{(1)}$, which appears, in this study, without predominance $(n=1,12.5 \%)$.

Some reasons can be considered, such as, in case the nursing graduation was the first training, the search for a second graduation may be due to nurses' dissatisfaction with their work, and in the situation in which nursing graduation was the second training, the search for this may be related to the idea of greater chances of employability in this field, due to its numerical hegemony in the health team ${ }^{(1,16)}$. For one reason or another, to a large extent, nurses have presented dual higher education.

Regarding participants' professional profile and, in particular, their work in teaching, it was found that the insertion of nurses in teaching took place, on average, 3 years after graduation and the majority ( $n=39,63.9 \%$ ) entered teaching within 2 years of graduation. Of course, the teaching career is a possibility for nurses' professional performance, which has been approaching this universe more and more frequently and rather precociously ${ }^{(17-18)}$. This approach happens, in many cases, without the necessary training for teaching so that, to teach, nurses end up using exclusively their theoretical-practical knowledge acquired at graduation and from professional experience ${ }^{(6-7)}$.

Therefore, it is opportune to reflect on how much nursing professors' teaching role can be compromised and weakened, due to the lack of specific training for teaching and the reduced time of care experience. The defense of teaching as a profession that requires the acquisition of knowledge that exceeds the limits of specificity is resumed, demanding specific training that takes into account the complexity that resides in teaching practice $^{(8-9)}$. Furthermore, the professional experience in nursing incorporates practical and experiential sense and knowledge to nurses' knowledge, which is important for teaching, adding real and experienced value to their teaching work. Acting in the training of future health professionals, therefore, requires skills for the teaching-learning process to be effective.

With regard to motivations for inclusion in teaching, the participants' answers focused on affinity with teaching $(n=22$, $36.1 \%)$, possibility of collaborating with the training of future professionals ( $n=16,26.2 \%$ ) and the opportunity to keep their knowledge in nursing always up to date $(n=13,21.3 \%)$. In the first analysis, identification with teaching is usually not the reason that nurses become professors, since teaching comes as a secondary option uncoupled from the choice by preference for teaching ${ }^{(19)}$. Therefore, the result presented in this study is quite positive, as it places nursing education in a central place of preference and not in a peripheral place.

Secondly, the mentioned motivating factors that refer to the contribution to the training of the other and of oneself point to an understanding of the responsibility of teaching and teachinglearning processes. Based on this understanding, nursing professors need to base their educational practice on social, ethical and SUS commitment, developing their work with quality ${ }^{(17)}$. It is highlighted, once again, the requirements inherent to the act of teaching and, consequently, the need for training for this work.

Also in this matter, the financial aspect, although timidly mentioned ( $n=5,8.2 \%)$, was also mentioned as a motivating factor for entering teaching. Unsurprisingly, nurses' salary income is often incompatible with the quantity and importance of their assignments, in such a way that they see in education a possibility of income supplementation ${ }^{(20-21)}$. For this reason, entry into teaching occurs much more as a matter of necessity and without the necessary training, which ends up compromising the very development of teaching activities.

As for the length of experience in teaching, most nurses ( $n=34$, $55.7 \%$ ) were novice professors, that is, they had 5 years or less of teaching experience. Making a parallel with the result exposed above, which showed that the majority entered teaching within 2 years of graduation, there is a scenario that signals for newly graduated nurses acting as professors for a short time. In fact, teaching at EPTNM in nursing has been commonly performed by new nurses who are also recent professors ${ }^{(7)}$, whose institutional bond is usually temporary, as found in this study $(n=57,93.4 \%)$. This reality, in which everything is very recent, fragile, full of discoveries and challenges, beckons the relevance of the discussion on the indispensability of professor training for nursing professors, and also of technical education in nursing, given that their role in teaching is almost always devoid of prior preparation, as well as its responsibility to train technical workers.

Thus, it is necessary and urgent to invest in professor training based on the (re)elaboration of consistent and continuous government and institutional policies. The scenario is one of denaturalization and deconstruction of the idea that it is enough to be a nurse to be a professor, which demands confrontation and promotion through the creation and strengthening of spaces for discussion on this topic, investment in research on this object and the implementation and development of initial and continuing education courses for teaching. Also, there 
needs to be a commitment by nurses to their qualification, with a view to teaching, in order to professionalize and qualify their teaching practice.

Regarding other experiences in nursing education, the majority $(n=29,82.8 \%)$ were undergraduate professors, in addition to the context of technical professional education. It is recommended, for teaching in higher education, stricto sensu graduate training in master's or doctoral courses ${ }^{(22-23)}$, considering that this is the legal requirement, without focusing here on the discussion that there is a certain prioritization in these courses for research to the detriment of teaching. When looking at the results in focus, which showed that a small portion of nurses had a master's or doctorate ( $n=10,17.9 \%)$, it appears that, also, at the higher level, as well as in the technical modality, the entry and performance of nurses as a professor has taken place without training directed to the exercise of this profession.

The need for this training was perceived by the participants themselves, given that, when asked if they considered it necessary, the majority $(n=58,95.1 \%)$ answered yes. On the other hand, almost half $(n=27,44.2 \%)$ did not have any type of qualification, considering the educational practice. Paying attention to this finding is, to say the least, intriguing, since the recognition of the need for training for teaching did not go hand in hand with the search for it. Seeking explanations for this would be challenging, but it is inevitable to think that teaching may be being trivialized, its complexities ignored, and demands minimized.

Also related to the professional profile, most nursing professors $(n=56,91.8 \%)$ had already worked in care, whose average time of entry into care practice was within 1 year of graduation and that of work in care it was 8 years. Nursing is a profession oriented to the practice of care, whose core lies in care with a view to health and well-being ${ }^{(24)}$. Thus, the experiential experience takes a significant place in nursing care, as it adds practical value and support to theoretical knowledge, as discussed above.

Furthermore, such care experience, by providing opportunities for approximation and appropriation of the reality of work in nursing, adds a sense of reality to nursing professors' educational practice so that the sharing and construction of knowledge for and in professional training become more concrete and tangible.

As for the place of care, the hospital and primary care networks were the main places mentioned by the participants, $(n=44,78.8 \%)$ and $(n=25,44.6 \%)$, respectively. It is known that nurses develop their activities predominantly in hospitals, and the basic network concentrates the second largest number of these professionals ${ }^{(25)}$. Here, therefore, there is a maintenance of this employability profile in nursing, which directs attention to the relevance of nurses' work, given that the population's health care takes place mainly in these types of care. Still, not only nurses' work of, but also nursing technicians', as these services also concentrate the largest contingent of this worker.

\section{Study limitations}

The study limitation is presented by the fact that it is descriptive, so that it was not possible to make an association of variables with more robust analyzes or correlation between the data presented, for example, between the region where the school is located and professors' profile.

\section{Contributions to nursing}

Nursing professors' training-professional profile points to the importance of the discussion about the qualification aimed at the exercise of teaching. The responsibility, complexity and challenges of teaching, especially in nursing in the context of professional education, make training for teaching an urgent need, considering the quality of technical training and care in nursing and health.

\section{CONCLUSIONS}

Nursing professors' training profile at the technical level showed that a minority were licensed and most graduates of lato sensu type with an area of concentration in nursing or health. The professional profile, in turn, focused on teaching practice showed, mainly, that most participants entered teaching within two years of their graduation, many of them by affinity with teaching, and despite the fact that most of them consider training necessary for teaching, almost half had no qualifications for this job. As for the professional profile with a focus on care, it was noticed that the average length of work in care was 8 years, whose work was concentrated in the hospital network.

These profiles indicate a role for nurses in nursing teaching in professional education without specific training for the teaching practice. In this perspective, the relevance of this theme is evident, as the training of workers at the technical level who have vital roles in health care and for the consolidation of SUS as a public policy is on the agenda.

In this way, it emphasizes the responsibility and need of nurses and training institutions, when hiring professors, to make permanent investment in continuing professor education. Teaching is an activity that has particularities, for which it is necessary to undertake its own knowledge and skills, therefore, it should be seen as a profession that requires a previous qualification.

Such investment will provide nursing professor with a teaching exercise based on the professionalism that this work requires and, consequently, will enable a qualified performance that will contribute to the consolidation and recognition of nursing and the rise of quality of care. In this sense, it is urgent to (re)think and (re)build policies, precise and without omissions regarding professor training, given the importance of the training process both at the technical and higher levels in nursing and health.

\section{FUNDING}

The study was funded by the Coordination for the Improvement of Higher Education Personnel (Coordenação de Aperfeiçoamento de Pessoal de Nível Superior), the Brazilian National Council for Scientific and Technological Development (Conselho Nacional de Desenvolvimento Científico e Tecnológico) and the Bahia State Research Support Foundation (Fundação de Amparo à Pesquisa do Estado da Bahia). 


\section{REFERENCES}

1. Machado MH, Wermelinger M, Vieira M, Oliveira E, Lemos W, Aguiar Filho W, et al. Aspectos gerais da formação da enfermagem: o perfil da formação dos enfermeiros técnicos e auxiliares. Enferm Foco. 2016;7(esp):15-34. https://doi.org/10.21675/2357-707X.2016.v7.nESP

2. Medeiros ESM, Prestes DRM, Pignata EKAA, Furtado RMS. Perfil do enfermeiro docente e sua percepção sobre a formação pedagógica. Rev Recien. 2018;8(24):42-53. https://doi.org/10.24276/rrecien2358-3088.2018.8.24.42-53

3. Conselho Federal de Enfermagem. Enfermagem em números [Internet]. [Brasília, DF]: COFEN; 2020 [cited 2020 Aug 10]. Available from: http://www.cofen.gov.br/enfermagem-em-numeros

4. Tafner DPOV, Reibnitz KS, Lazzari DD. Implementation of the integrality principle in technical nursing courses at schools in the SUS network. Texto Contexto Enferm. 2016;25(4):e3470015. https://doi.org/10.1590/0104-07072016003470015

5. Ribeiro-Barbosa JC, Silva GTR, Amestoy SC, Silva CCR, Silva RMO, Backes VMS. Technical schools of the unified health system: an analysis of nursing education. Rev Esc Enferm USP. 2020;54:e03580. https://doi.org/10.1590/S1980-220X2018052503580

6. Corrêa AK, Sordi MRL. The secondary technical-professional education in the unified health system and the teacher training policy. Texto Contexto Enferm. 2018;27(1):e2100016. https://doi.org/10.1590/0104-07072018002100016

7. Souza DM, Backes VMS, Lazzari DD, Santos LMC, Martini JG. Conhecimento pedagógico de conteúdo de docentes de enfermagem novatos na educação técnica de nível médio. Rev Bras Enferm. 2020;73(5):e20180976. https://doi.org/10.1590/0034-7167-2018-0976

8. Shulman LS. Conhecimento e ensino: fundamentos para a nova reforma. Cad Cenpec. 2014;4(2):196-229. https://doi.org/10.18676/ cadernoscenpec.v4i2.293

9. Nóvoa A. Firmar a posição como professor, afirmar a profissão docente. Cad Pesqui. 2017;47(166):1106-33. https://doi.org/10.1590/198053144843

10. Mancuso ACB, Castro SMJ, Guimarães LSP, Leotti VB, Hirakata VN, Camey SA. Estatística descritiva: perguntas que você sempre quis fazer, mas nunca teve coragem. Clin Biomed Res. 2018;38(4):414-8. https://doi.org/10.4322/2357-9730.89242

11. Rampellotti LF, Pasqualli R. O bom professor enfermeiro: o olhar dos estudantes de cursos técnicos acerca da prática docente. Rev Exitus. 2020;10:e020027. https://doi.org/10.24065/2237-9460.2020v10n0id1251

12. Backes VMS, Menegaz JC, Miranda FAC, Santos LMC, Cunha AP, Patrício SS. Lee Shulman: contributions to research on teacher training. Texto Contexto Enferm. 2017;26(4):e1080017. https://doi.org/10.1590/0104-07072017001080017

13. Corrêa AK, Prebill GM, Ruiz JC, Souza MCBM, Santos RA. First-year student profile in the "bachelor's degree with a teaching credential in nursing" program at a brazilian public university. Educ Rev. 2018;34:e185913. https://doi.org/10.1590/0102-4698185913

14. Hott MCM, Reinaldo AMS. Qualificação pedagógica de enfermeiros docentes em cursos profissionalizantes. Rev Bras Educ Prof Tecnologica. 2018;2(15):e6455. https://doi.org/10.15628/rbept.2018.6455

15. Sordi MRL. Docência no ensino superior: interpelando os sentidos e desafios dos espaços institucionais de formação. Educ Rev. 2019;35(75):135-54. https://doi.org/10.1590/0104-4060.67031.

16. Frota MA, Wermelinger MCMW, Vieira LJES, Ximenes Neto FRG, Queiroz RSM, Amorim RF. Mapping nursing training in Brazil: Challenges for actions in complex and globalized scenarios. Cienc Saude Colet. 2020;25(1):25-35. https://doi.org/10.1590/1413-81232020251.27672019

17. Agnelli JCM, Nakayama BCMS. Constituição docente do enfermeiro: possibilidades e desafios. Rev Ambient Educ. 2018;11(3):334-44. https:// doi.org/10.26843/ae19828632v11n32018p328a344

18. Santos LMC, Souza DM, Backes VMS, Reibnitz KS. Educação profissional técnica de nível médio. In: Backes VMS, Menrgaz JC, Moya JLM, organizadores. Formação docente na saúde e enfermagem. Porto Alegre: Moriá; 2019. p. 173-89.

19. Sgarbi AKG, Missio L, Renovato RD, Hortelan MPSM. Enfermeiro docente no ensino técnico em enfermagem. Laplage Rev. 2018;4(1):254-73. https://doi.org/10.24115/s2446-6220201841423p.254-273

20. Machado MH, Oliveira E, Lemos W, Lacerda WF, Aguiar Filho W, Wermelinger M, et al. Mercado de trabalho da enfermagem: aspectos gerais. Enferm Foco. 2016;7(esp):35-62. https://doi.org/10.21675/2357-707X.2016.v7.nESP.691

21. Souza DM, Backes VMS, Lazzari DD, Martini JG. Pedagogical preparation of nursing professors for professional secondary technical education. Rev Bras Enferm. 2018;71(5):2432-9. https://doi.org/10.1590/0034-7167-2017-0289

22. Menegaz JC, Zamprogna KM, Backes VMS. Formação docente de ensino superior em diferentes contextos educacionais: reconhecimento para a construção de comunidades de prática. In: Backes VMS, Menegaz JC, Moya JLM, organizadores. Formação docente na saúde e enfermagem. Porto Alegre: Moriá; 2019. p. 119-36.

23. Ministério da Educação (BR). Lei no 9.394, de 20 de dezembro de 1996. Estabelece as diretrizes e bases da educação nacional. [Brasília, DF: ME]; 1996.

24. Queirós PJP. The knowledge in nursing and the source of this knowledge. Esc Anna Nery. 2016;20(3):e20160079. https://doi. org/10.5935/1414-8145.20160079

25. Machado MH, Oliveira ES, Lemos WR, Lacerda WF, Justino E. Mercado de trabalho em enfermagem no âmbito do SUS: uma abordagem a partir da pesquisa perfil da enfermagem no Brasil. Divulg Saude Debate [Internet]. 2016[cited 2020 Jul 31];(56):52-69. Available from: http:// docs.bvsalud.org/biblioref/2019/04/884409/mercado-de-trabalho-em-enfermagem-no-ambito-do-sus-uma-abordage_Uir6lGY.pdf 